\title{
Investigation of a Cu/Pd Bimetallic System Electrodeposited on Boron-Doped Diamond Films for Application in Electrocatalytic Reduction of Nitrate
}

\author{
Jorge T. Matsushima, ${ }^{1}$ Valéria C. Fernandes, ${ }^{2}$ Andrea B. Couto, ${ }^{1}$ \\ Maurício R. Baldan, ${ }^{1}$ and Neidenêi G. Ferreira ${ }^{1}$ \\ ${ }^{1}$ Laboratório Associado de Sensores e Materiais (LAS), Instituto Nacional de Pesquisas Espaciais_INPE, 12.245-970 \\ São José dos Campos, SP, Brazil \\ ${ }^{2}$ Instituto de Pesquisa Energéticas e Nucleares-IPEN, Centro de Células a Combustível e Hidrogénio (CCCH), 05508-000 \\ São Paulo, SP, Brazil \\ Correspondence should be addressed to Jorge T. Matsushima, jtmatsushima@yahoo.com.br
}

Received 31 March 2011; Revised 7 June 2011; Accepted 5 July 2011

Academic Editor: Giancarlo R. Salazar-Banda

Copyright ( $\odot 2012$ Jorge T. Matsushima et al. This is an open access article distributed under the Creative Commons Attribution License, which permits unrestricted use, distribution, and reproduction in any medium, provided the original work is properly cited.

The $\mathrm{Cu} / \mathrm{Pd}$ bimetallic system electrodeposited on boron-doped diamond (BDD) films for application, as electrode material in the electrochemical reduction of nitrate was studied. The electrochemical behavior of $\mathrm{Cu}, \mathrm{Pd}$, and $\mathrm{Cu} / \mathrm{Pd}$ bimetallic system was evaluated by cyclic voltammetry. From these results, the formation of the $\mathrm{Cu} / \mathrm{Pd}$ composite was verified. In addition, $\mathrm{Cu}$ with different phases and a $\mathrm{Cu} / \mathrm{Pd}$ phase in the composite were obtained. Morphological analysis by scanning electron microscopy (SEM) revealed a homogeneous distribution of $\mathrm{Cu} / \mathrm{Pd}$ bimetallic particles with intermediary dimensions compared to those observed in $\mathrm{Cu}$ or Pd electrodeposits separately. These composites were tested as electrocatalysts for nitrate reduction in BrittonRobinson buffer solution ( $\mathrm{pH}$ 9). Electrochemical measurements showed that composites with higher Cu content displayed the best electrocatalytic activity for nitrate reduction, and the $\mathrm{Cu} / \mathrm{Pd}$ phase in the bimetallic system served to improve the Cu adherence on BDD electrode.

\section{Introduction}

The contamination of ground and surface waters by nitrate ions has been considered a common environmental problem, especially because of the large use of nitrogen-based compounds in agriculture and industrial wastes. The necessary control and removal of nitrate ions has stimulated intensive research, because nitrate causes detrimental effects not only on human health but also on aquatic ecosystems $[1,2]$. The methods which are often used for the reduction of nitrate are biological denitrification and ion exchange. However, these methods have some drawbacks such as continuous monitoring, slow kinetics, and sthe generation of byproduct. On the other hand, electrochemical methods have received a great deal of attention because of their advantages such as the use of clean reagents (electrons) and their low cost.
The majority of papers which deal with the electrochemical reduction of nitrate demonstrate the reaction efficiency of the single metal electrode [3-6], while some papers show the viability of the boron-doped diamond (BDD) films as an electrode material, for the electrochemical reduction of nitrate [7-10]. Particularly, BDD films are excellent electrode materials for this purpose, because of their singular physicochemical properties such as low background currents, wide potential window which analyzes the chemical species without involving water decomposition reaction, high corrosion resistance, and mechanical stability $[11,12]$. In spite of the thermodynamic feasibility of the nitrate reduction, the charge transfer kinetics on BDD electrode is slow and direct reduction of nitrate has been characterized by poor sensitivity and selectivity of these electrodes. In this sense, the surface modification with a 
specific electrocatalysts has been an important strategy to improve their electrocatalytics properties. In general, binary metal electrodes in the form of alloys $[13,14]$, codeposited films [15], or electrodes modified with foreign adatoms on their surface [16-21] have been some of the strategies used to enhance the electrode properties concerning to the electrochemical reduction of nitrate.

It is important to emphasize that BDD electrodes, due to the inert nature of their surface, are a natural substrate to make the surface modification without any major interference. Moreover, their mechanical and chemical stability permit the surface modification in the extreme conditions of preparation (e.g., high temperature) without any significant modification of the surface properties. The surface modification of BDD electrodes with Au [22-24] and Pt [25-27] nanoparticles were carried out, and interesting results were obtained. Such modifications increased the electrocatalytic activity for oxygen reduction and methanol oxidation. Recent studies also showed that the surface modification of the BDD electrodes with $\mathrm{Cu}$ nanoparticles obtained by simple electrochemical deposition was used to detect nitrate electrochemically using an in situ method $[28,29]$. Besides, $\mathrm{Cu}$ exhibits the best electrocatalytic activity for electrochemical reduction of nitrate when compared to other materials like $\mathrm{Ni}$, graphite, and $\mathrm{Pt}$ [30]. However, the modified BDD electrode is limited by the poor surface adherence, by the formation of toxic subproducts (nitrite and ammonia), and by the cumulative passivation effect. Up to now, bimetallic $\mathrm{Cu} / \mathrm{Pd}$ electrocatalyst is considered one of the most promising materials with maximum selectivity for $\mathrm{N}_{2}$ of $60 \%-70 \%$, which is justified by its bifunctional character, in which nitrate is reduced on $\mathrm{Cu}$ sites into $\mathrm{NO}_{2}{ }^{-} / \mathrm{NO}$, and subsequently reduced into $\mathrm{N}_{2}$ on $\mathrm{Pd}$ sites $[31,32]$. Moreover, the $\mathrm{Cu}$ poor adherence, previously mentioned, could also be improved when prepared in the alloy form or composite. In order to obtain such conditions, the choice of preparation method is of fundamental importance. Among the several methods used for production of alloys and composites, the electrodeposition is an interesting method due to their simplicity, their compatibility of the processing at room temperature, and their controllability of thin film properties.

To the best of our knowledge, the production of $\mathrm{Cu} / \mathrm{Pd}$ bimetallic system on BDD electrodes by electrodeposition has not been studied. Nevertheless, some papers present the advantages of a $\mathrm{Cu} / \mathrm{Pd}$ system electrodeposited as alloys or composite [31-35]. Vinogradov et al. succeeded in the deposition $\mathrm{Cu} / \mathrm{Pd}$ alloys coating with good physicomechanical properties [33]. Recently, Milhano and Pletcher produced $\mathrm{Cu} / \mathrm{Pd}$ alloys coating Pt by coelectrodeposition [34]. Cu/Pd composites (without reaction between $\mathrm{Cu}$ and $\mathrm{Pd}$ ) were also prepared by electrodeposition [31,32]. Thus, this work associates the singular properties of BDD films, as electrode material, with the best conditions for the production of the $\mathrm{Cu} / \mathrm{Pd}$ bimetallic system on BDD electrode. In addition, it is used as a possible composite material to be applied to the electrochemical reduction of nitrate.

\section{Experimental}

The BDD films were grown on silicon by hot filamentassisted vapor deposition (HFCVD) technique. The filament temperature was kept constant at $780^{\circ} \mathrm{C}$. The deposition was performed for $7 \mathrm{~h}$, and a gaseous mixture of $99 \%$ vol. $\mathrm{H}_{2}$ and $1 \%$ vol. $\mathrm{CH}_{4}$ and a total pressure of 50 Torr were used. The boron doping was obtained from $\mathrm{H}_{2}$ forced to pass through a bubbler containing $\mathrm{B}_{2} \mathrm{O}_{3}$ dissolved in methanol. From the Mott Schottky plot, the doping level was estimated to approximately $10^{20}$ boron atoms $\cdot \mathrm{cm}^{-3}$ [36]. The morphology of the BDD films was analyzed by scanning electronic microscopy (SEM) using a Jeol equipment JSM-5310, while that the quality was evaluated by micro-Raman scattering spectroscopy (Renishaw microscope system 2000) in backscattering configuration at room temperature employing $514 \mathrm{~nm}$ argon-ion laser.

All electrolytic solutions were prepared using ultrapure water from a Millipore water purifier system and analytical grade reagents were used. Prior to the experiments, the electrolytic solutions were deaerated with $\mathrm{N}_{2}$ gas during $10 \mathrm{~min}$.

Electrochemical measurements were performed using Autolab PGSTAT 302 equipment with a three-electrode cell. The BDD films were used as working electrode. The geometric area in contact with the electrolyte was $0.27 \mathrm{~cm}^{2}$. A platinum coil wire served as a counter electrode and $\mathrm{Ag} / \mathrm{AgCl}$ electrode was chosen as the reference electrode.

Electrochemical behavior of the $\mathrm{Cu}$ and $\mathrm{Pd}$ on BDD electrodes was studied by cyclic voltammetry from solutions containing $5 \mathrm{mM} \mathrm{Cu}(\mathrm{II})+0.5 \mathrm{M} \mathrm{HClO}_{4}$ and $1 \mathrm{mM} \mathrm{Pd}(\mathrm{II})$ $+0.5 \mathrm{M} \mathrm{HClO}_{4}$. The solutions containing $\mathrm{Cu}(\mathrm{II})$ and $\mathrm{Pd}(\mathrm{II})$ were prepared using $\mathrm{CuSO}_{4}$ and $\mathrm{PdCl}_{2}$ salts, respectively. With respect to the $\mathrm{Cu} / \mathrm{Pd}$ composite, electrochemical studies were also realized by cyclic voltammetry using solutions containing different $\mathrm{Cu}(\mathrm{II})$ concentrations $(1,5$ and $10 \mathrm{mM} \mathrm{CuSO}_{4}$ ), where in these solutions, $1 \mathrm{mM} \mathrm{Pd(II)}$ and $0.5 \mathrm{M} \mathrm{HClO}_{4}$ were maintained constant. So, $(1: 1)$, $(5: 1)$, and $(10: 1) \mathrm{Cu}(\mathrm{II}): \mathrm{Pd}(\mathrm{II})$ ratio were used. Prior each electrochemical measurement, a mixture $(3: 1) \mathrm{HCl} / \mathrm{HNO}_{3}$ ratio was used to clean the BDD surface. After this, BDD films maintained the same physicochemical characteristics verified in the SEM and Raman analysis.

$\mathrm{Cu} / \mathrm{Pd}$-modified BDD electrodes were produced under constant potential. Morphological analysis of the $\mathrm{Cu} / \mathrm{Pd}$ composite and their composition were examined by a scanning electron microscopy (Jeol equipment JSM-5310) incorporating an energy dispersive X-ray (EDX) unit with a software for elemental analysis. In order to evaluate the composition uniformity ( $\mathrm{Cu}$ and Pd content), multiple EDX spectra were recorded at different points over the BDD surface. Electrochemical reduction of nitrate was investigated by linear sweep voltammetry (LSV) as a function of time and deposition potential and also the $\mathrm{Cu}(\mathrm{II}): \mathrm{Pd}(\mathrm{II})$ ratio used for electrodeposition of the $\mathrm{Cu} / \mathrm{Pd}$ composite on $\mathrm{BDD}$ electrode. A Britton-Robinson (BR) buffer solution ( $\mathrm{pH} 9.0$ ) without and with $0.1 \mathrm{M} \mathrm{KNO}_{3}$ were used in our studies. 


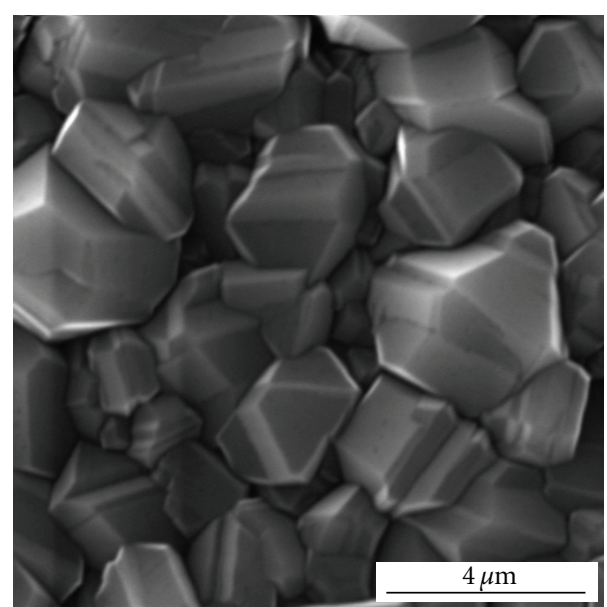

(a)

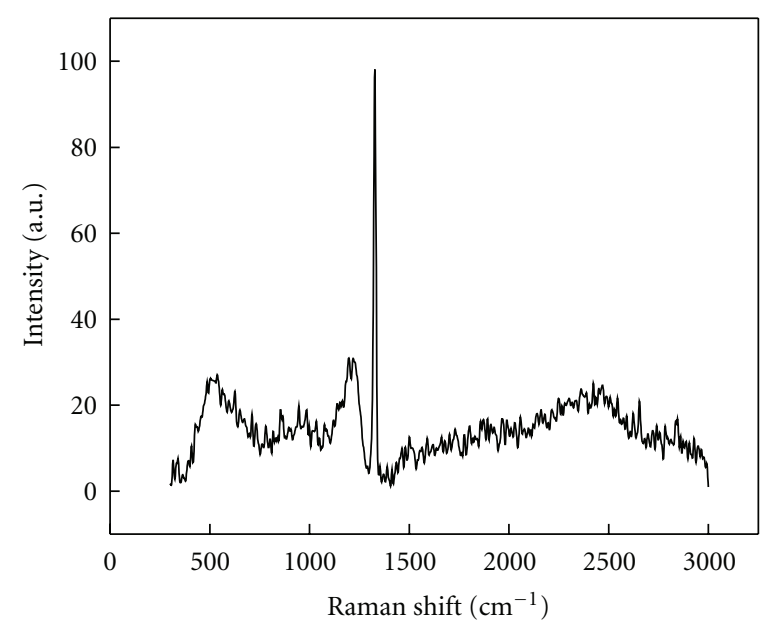

(b)

FIgURE 1: (a) SEM image and (b) Raman spectrum of the BDD film.

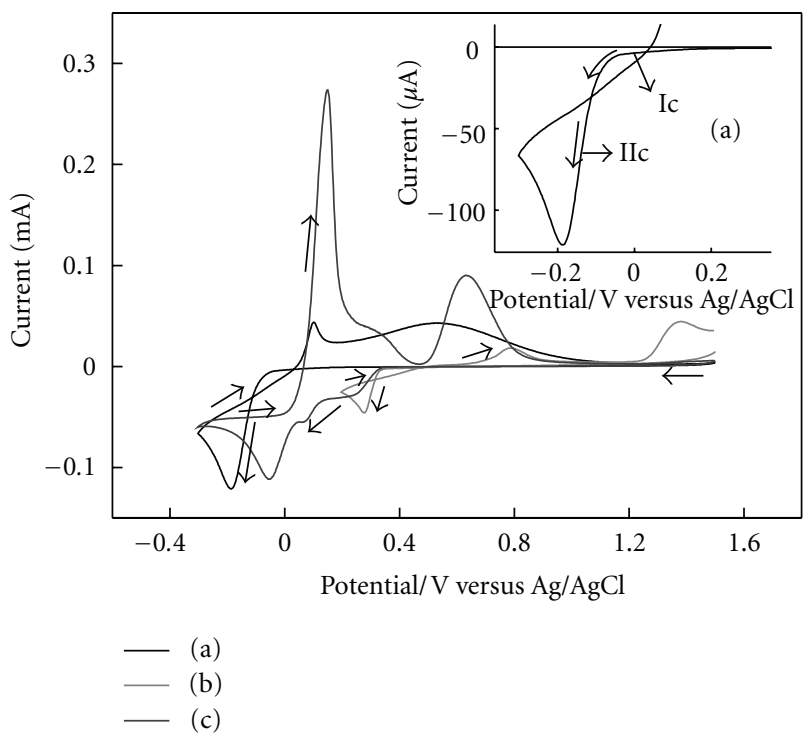

FIGURe 2: Cyclic voltammograms of the BDD electrode in solutions containing (a) $5 \mathrm{mM} \mathrm{Cu}$ (II), (b) $1 \mathrm{mM} \mathrm{Pd(II),} \mathrm{and} \mathrm{(c)} 5 \mathrm{mM} \mathrm{Cu(II)}$ $+1 \mathrm{mM} \mathrm{Pd}(\mathrm{II})$. All solutions containing $0.5 \mathrm{M} \mathrm{HClO}_{4}$ as supporting electrolyte. Scan rate of $10 \mathrm{mVs}^{-1}$.

\section{Results and Discussion}

Morphological and structural characterization of BDD films was carried out prior to electrochemical experiments. Figure 1(a) shows the SEM image of the BDD film. The morphological aspect shows a film formed by symmetric and faceted grains with a uniform texture. The Raman spectra presented in Figure 1(b) confirms the quality of BDD films even after the chemical treatment with $(3: 1)\left(\mathrm{HCl}: \mathrm{HNO}_{3}\right)$ ratio. From the Raman spectroscopy is observed a peak at $\sim 1320 \mathrm{~cm}^{-1}$ that is characteristic of the diamond. This peak presented a shift to lower energies due to tensions caused by boron incorporation in the diamond films. In addition, the spectrum presented two bands located at $500 \mathrm{~cm}^{-1}$ and at $1230 \mathrm{~cm}^{-1}$ that are associated to boron incorporation in the diamond films $[37,38]$.

In order to investigate the possible formation of a $\mathrm{Cu} / \mathrm{Pd}$ alloy or composite on the BDD electrode, cyclic voltammetry measurements were carried out. Three different solutions were used in these experiments: one solution containing only $\mathrm{Cu}(\mathrm{II})$, the other one containing only $\mathrm{Pd}(\mathrm{II})$, and last one containing the mixture of the two metal ions. Figure 2 illustrates the cyclic voltammograms of the BDD electrode recorded at these three solutions. The curve (a) was studied in the solution containing only $\mathrm{Cu}$ (II), the curve (b) only $\operatorname{Pd}(\mathrm{II})$ and curve (c) a mixture of the two metal ions. The curve (a) represents the electrochemical behavior of the $\mathrm{Cu}$ in $5 \mathrm{mM} \mathrm{Cu}(\mathrm{II})+0.5 \mathrm{M} \mathrm{HClO}_{4}$ solution. The inset of the Figure 2(a) evidence the two regions of $\mathrm{Cu}$ cathodic current, labeled as (Ic) and (IIc). The first region (Ic) that begins at a more positive potential may be associated to underpotential deposition (UPD) (or intercalation) of $\mathrm{Cu}$. The second region (IIc) is related to the region of bulk $\mathrm{Cu}$ deposition. According to Bouamrane et al., the occurrence of the UPD of $\mathrm{Cu}$ is related to the BDD surface condition, where it was verified to happen only in the crystalline defects, probably in the graphitic inclusions ( $\mathrm{sp}^{2}$ carbon sites) [39]. Besides, the UPD has been observed in other forms of carbon such as pyrolytic graphite, where it is believed to occur at $\mathrm{sp}^{2}$ carbon sites which cannot be completely avoided [40]. The reverse sweep shows significant hysteresis that is consistent with the $\mathrm{Cu}$ deposition reaction involving nucleation as well as growth of the $\mathrm{Cu}$ layer. The $\mathrm{Cu}$ deposition continues to $0.0 \mathrm{~V}$, and immediately after that, the $\mathrm{Cu}$ stripping is accompanied by two anodic current regions. A welldefined anodic peak at $0.05 \mathrm{~V}$ is associated to the maximum current of bulk $\mathrm{Cu}$ stripping followed by a large potential region, involving the anodic current due to the stripping of other deposited $\mathrm{Cu}$ phase. The overall charge balance, $Q_{\text {anodic }} / Q_{\text {cathodic }}$ ratio close to 1.0 , shows that all deposited $\mathrm{Cu}$ was dissolved after the end of the reverse sweep. The 
curve (b) represents the electrochemical behavior of the $\mathrm{Pd}$ in $1 \mathrm{mM} \mathrm{Pd}(\mathrm{II})+0.5 \mathrm{M} \mathrm{HClO}_{4}$ solution. The Pd deposition occurred at $0.35 \mathrm{~V}$ where a well-formed reduction wave was observed. The negative potential sweep was limited at $0.2 \mathrm{~V}$, because from this potential, high current is observed due to hydrogen absorption into the Pd surface/lattice. Again, the reverse sweep shows substantial hysteresis with deposition continuing to $0.47 \mathrm{~V}$. In this case, the $Q_{\text {anodic }} / Q_{\text {cathodic }}$ ratio was 0.47 , indicating an incomplete redisolution of the $\mathrm{Pd}$. The $Q_{\text {anodic }}$ fraction indicates the residual Pd on the BDD surface, where an anodic process with a current maximum at $1.4 \mathrm{~V}$ is associated to the formation of the palladium oxide. The curve (c) represents the cyclic voltammogram of the $\mathrm{Cu} / \mathrm{Pd}$ system obtained in $5 \mathrm{mM} \mathrm{Cu}$ (II) $+1 \mathrm{mM}$ $\mathrm{Pd}(\mathrm{II})+0.5 \mathrm{M} \mathrm{HClO}_{4}$ solution. The deposition of the $\mathrm{Cu} / \mathrm{Pd}$ system occurred in the same region of $\mathrm{Pd}$ deposition. The deposition process is characterized by three cathodic waves with the current maximum localized at $0.23 \mathrm{~V}, 0.07 \mathrm{~V}$, and $-0.05 \mathrm{~V}$. This behavior may be associated with the electrodeposition of a $\mathrm{Cu} / \mathrm{Pd}$ composite on BDD electrode. In this case, no alloy formation was verified (simultaneous coelectrodeposition). The more positive cathodic wave may be attributed to the reduction of $\mathrm{Pd}$ (II) to metallic Pd. This process was confirmed from the voltammetric study (not shown in this work). In this study, the potential sweep was reverted at $-0.35 \mathrm{~V}$ near to the maximum current involved in the Pd deposition and revealed only the presence of the $\mathrm{Pd}$ deposition. As response, the resulting anodic process presented the same behavior of $\mathrm{Pd}$ dissolution as seen in the curve (b). The cathodic wave located at $0.07 \mathrm{~V}$ may be associated with the onset of the $\mathrm{Cu}$ deposition with different phases. One of phases may be attributed to the UPD of $\mathrm{Cu}$, since it is observed at a potential region near to occurrence of the Cu UPD process, as it was discussed earlier during the electrochemical studies of $\mathrm{Cu}$. On the other hand, the more negative cathodic wave at $-0.05 \mathrm{~V}$ is confirmed to be the bulk $\mathrm{Cu}$ phase deposition. In spite of the more positive potential about $100 \mathrm{mV}$ compared to bulk $\mathrm{Cu}$ deposition, the occurrence of this process is confirmed from the analysis of the reversing potential sweep, since the more positive anodic process, associated to the bulk $\mathrm{Cu}$ phase dissolution, begins at the same dissolution potential of the bulk $\mathrm{Cu}$. Continuing the sweep to a more positive potential, an anodic current shoulder at $0.3 \mathrm{~V}$ is attributed to oxidation of a $\mathrm{Cu}$ phase followed by an anodic current wave at $0.63 \mathrm{~V}$. The shifted potential to a more negative value and a high anodic charge compared to $\mathrm{Pd}$ dissolution process show the dissolution of a $\mathrm{Cu} / \mathrm{Pd}$ phase initially electrodeposited during the negative potential sweep.

The investigation of the $\mathrm{Cu} / \mathrm{Pd}$ composite on $\mathrm{BDD}$ electrode was carried out for three other solutions, where the $\mathrm{Pd}(\mathrm{II})$ concentration was maintained constant and $\mathrm{Cu}$ (II) concentration was varied. In this study, this condition was defined considering the best composition of $\mathrm{Cu} / \mathrm{Pd}$ bimetallic system. As reported by Milhano and Pletcher [34], nitrate is not reduced at the Pd surface but occurs at the CuPd surface, so it is necessary to have greater $\mathrm{Cu}$ amount due to their high electrocatalytic activity for electrochemical reduction of nitrate. In this case, the choice of $\mathrm{Pd}$ for the

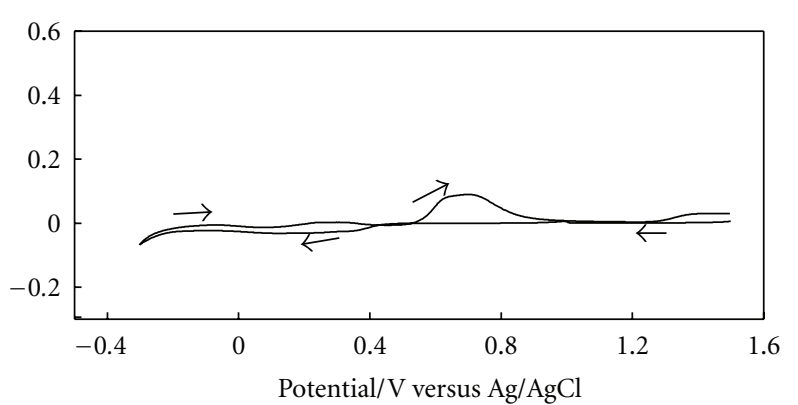

(a)

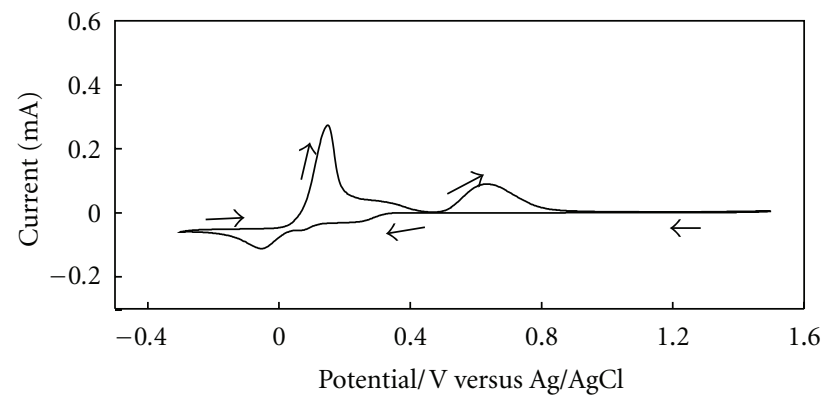

(b)

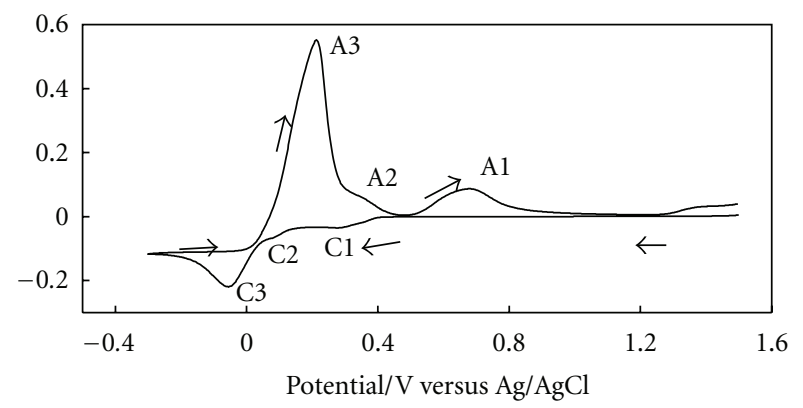

(c)

FIGURE 3: Cyclic voltammograms of BBD electrode in solutions with (a) $(1: 1)$, (b) $(5: 1)$, and (c) $(10: 1) \mathrm{Cu}$ (II) $: \mathrm{Pd}$ (II) ratio. Scan rate of $10 \mathrm{mV} \mathrm{s}^{-1}$.

production of a composite with $\mathrm{Cu}$ on BDD electrodes was made in an attempt to enhance the physical chemical properties of the $\mathrm{Cu} / \mathrm{Pd}$ composite due to binding energy between $\mathrm{Pd}$ and $\mathrm{Cu}$ and also to provide active sites for obtaining nontoxic subproducts during the electrochemical reduction of nitrate.

Figure 3 presents the cyclic voltammograms of the $\mathrm{Cu} / \mathrm{Pd}$ composite on BDD electrode in solutions with different $\mathrm{Cu}(\mathrm{II}): \mathrm{Pd}(\mathrm{II})$ ratio. From voltammetric profiles is observed that the deposition of the $\mathrm{Cu} / \mathrm{Pd}$ composite begins practically in the same potential region independently of the $\mathrm{Cu}(\mathrm{II}): \mathrm{Pd}(\mathrm{II})$ ratio. In all the profiles presented, the occurrence of the two cathodic processes (C1 and C2) was observed. These processes are associated with the bulk $\mathrm{Pd}$ deposition and the $\mathrm{Cu}$ phase deposition, respectively. However, the C3 process was not evidenced for the $(1: 1)$ $\mathrm{Cu}(\mathrm{II})$ : $\mathrm{Pd}(\mathrm{II})$ ratio. Although an increase of the cathodic peak current intensity at $-0.05 \mathrm{~V}$ was observed with the 


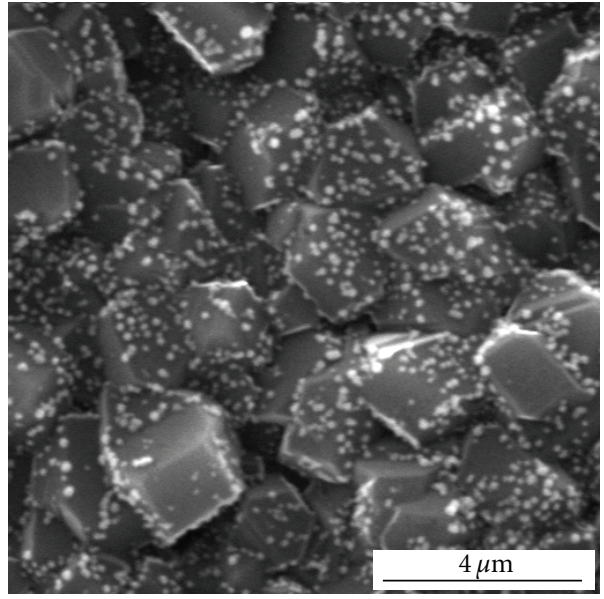

(a)

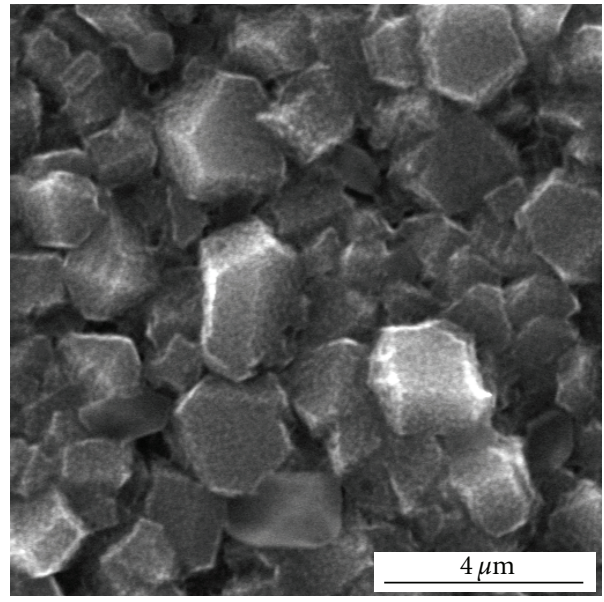

(b)

FIgure 4: SEM images of (a) Cu and (b) Pd electrodeposited on BDD electrode. Both were deposited by $120 \mathrm{~s}$, and $-0.3 \mathrm{~V}$ and $0.2 \mathrm{~V}$ were applied to deposit $\mathrm{Cu}$ and $\mathrm{Pd}$, respectively.

increase of the $\mathrm{Cu}(\mathrm{II}): \mathrm{Pd}(\mathrm{II})$ ratio in the solution. This result shows that increasing the $\mathrm{Cu}(\mathrm{II}): \mathrm{Pd}(\mathrm{II})$ ratio, thermodynamically, the simultaneous codeposition of $\mathrm{Cu}$ and $\mathrm{Pd}$ was not favored. Then, no alloying between $\mathrm{Cu}$ and $\mathrm{Pd}$ occurred. In this case, it may be only due to bulk $\mathrm{Cu}$ deposition with high $\mathrm{Cu}$ content in the $\mathrm{Cu} / \mathrm{Pd}$ composite formed. In particular, hydrogen evolution reaction in the solution with $(1: 1) \mathrm{Cu}(\mathrm{II}): \mathrm{Pd}(\mathrm{II})$ ratio was observed, due to high density of catalytic Pd sites that favored the reaction. The anodic processes (A1, A2, and A3) were observed in solutions with $(5: 1)$ and $(10: 1) \mathrm{Cu}(\mathrm{II}): \mathrm{Pd}(\mathrm{II})$ ratio, and it may be associated to dissolution of $\mathrm{Cu}$ with different phases (A3 and $\mathrm{A} 2$ processes) and a $\mathrm{Cu} / \mathrm{Pd}$ phase (A1 process) as reported earlier. The absence of $\mathrm{A} 3$ process in solution with $(1: 1) \mathrm{Cu}(\mathrm{II}): \mathrm{Pd}(\mathrm{II})$ ratio shows that the bulk $\mathrm{Cu}$ deposition did not occur. The highest anodic current intensity (A3 process) observed in solution with $(10: 1)$ $\mathrm{Cu}(\mathrm{II}): \mathrm{Pd}(\mathrm{II})$ ratio indicates a more bulk $\mathrm{Cu}$ dissolution. In this process, the same current plateau commencing at $0.07 \mathrm{~V}$ represents a diffusion-controlled dissolution process. On the other hand, a current shoulder at $-0.08 \mathrm{~V}$ (A2 process) and an anodic wave with current maximum at $0.63 \mathrm{~V}$ (A1 process) were observed in all $\mathrm{Cu}(\mathrm{II}): \mathrm{Pd}(\mathrm{II})$ ratio. Independently of the $\mathrm{Cu}(\mathrm{II}): \mathrm{Pd}(\mathrm{II})$ ratio, the anodic charge $(\sim 2.1 \mathrm{mC})$ corresponding to the A1 process presented the same value, indicating the dissolution of an identical $\mathrm{Cu} / \mathrm{Pd}$ phase. The onset of the $\mathrm{Cu} / \mathrm{Pd}$ phase dissolution at a more negative potential confirms the dissolution of a less noble phase compared to bulk Pd phase, as can be seen in Figure 1.

The electrochemical characterization of the $\mathrm{Cu}, \mathrm{Pd}$, and $\mathrm{Cu} / \mathrm{Pd}$ composite on BDD electrode was accompanied by morphological and elemental composition analysis. Figure 4, shows the SEM images of the (a) $\mathrm{Cu}$ electrodeposited at $-0.3 \mathrm{~V}$ for $120 \mathrm{~s}$ from a solution containing $5 \mathrm{mM} \mathrm{Cu}$ (II) $+0.5 \mathrm{M} \mathrm{HClO}_{4}$ and (b) $\mathrm{Pd}$ electrodeposited at $0.2 \mathrm{~V}$ for $120 \mathrm{~s}$ from a $1 \mathrm{mM} \mathrm{Pd}(\mathrm{II})+0.5 \mathrm{M} \mathrm{HClO}_{4}$. The deposition potential was defined from a region controlled by diffusion. In Figure 4(a), the SEM image reveals that $\mathrm{Cu}$ submicron $(\sim 100 \mathrm{~nm})$ particles are uniformly distributed all over the BDD surface. In the case of the Pd, nanoparticles homogeneously distributed on BDD surface were produced, as shows the Figure 4(b). On the basis of these results, the morphology of the $\mathrm{Cu} / \mathrm{Pd}$ composite on BDD electrodes became easier to be analyzed. The composites were produced at $-0.3 \mathrm{~V}$ during $120 \mathrm{~s}$ from the solutions containing different $\mathrm{Cu}(\mathrm{II}): \mathrm{Pd}(\mathrm{II})$ ratio. The SEM images are shown in Figure 5. As can be seen, all electrodeposited films were uniformly distributed on BDD electrodes. However, the size and distribution of the film particles are dependent of the solution composition. In $\mathrm{Cu} / \mathrm{Pd}$ composite produced at $(1: 1) \mathrm{Cu}(\mathrm{II}): \mathrm{Pd}(\mathrm{II})$ ratio, the morphology of this particles presented intermediary dimensions compared to those of $\mathrm{Cu}$ and $\mathrm{Pd}$ electrodeposited separately. Probably, this coating refers to the deposition of a $\mathrm{Cu} / \mathrm{Pd}$ phase (Figure 5(a)). This affirmation is consistent with the electrochemical results, since the bulk $\mathrm{Cu}$ deposition in this solution composition was not observed, as can be seen in Figure 3(a). By increasing the $\mathrm{Cu}(\mathrm{II})$ concentration, a coating of a bulk $\mathrm{Cu}$ phase (Figures $5(\mathrm{~b})$ and $5(\mathrm{c})$ ) at $\mathrm{Cu} / \mathrm{Pd}$ composite was produced, since particles distribution over BDD electrode with similar dimensions to that of the $\mathrm{Cu}$ electrodeposit was verified. By analyzing the electrochemical behavior of the $\mathrm{Cu} / \mathrm{Pd}$ composites produced at $(5: 1)$ and $(10: 1) \mathrm{Cu}(\mathrm{II}): \mathrm{Pd}(\mathrm{II})$ ratio, as discussed earlier in Figures 3(b) and 3(c), the morphological aspect involving particles of larger dimensions compared to $\mathrm{Cu} / \mathrm{Pd}$ composite produced at $(1: 1) \mathrm{Cu}(\mathrm{II}): \mathrm{Pd}(\mathrm{II})$ ratio is associated to effect of bulk $\mathrm{Cu}$ deposition.

In order to obtain the $\mathrm{Cu}$ and $\mathrm{Pd}$ content in these composites, EDX analysis was carried out considering several local points $(1 \times 1 \mu \mathrm{m})$ on BDD surface as function of the $\mathrm{Cu}(\mathrm{II}) / \mathrm{Pd}(\mathrm{II})$ ratio. Table 1 illustrates the elemental composition for each $\mathrm{Cu} / \mathrm{Pd}$ composite. As expected, higher $\mathrm{C}$ content is associated with the diamond composition. On 


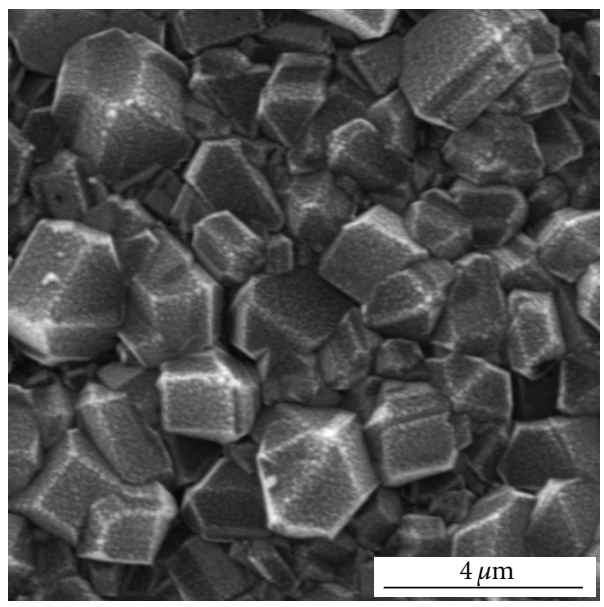

(a)

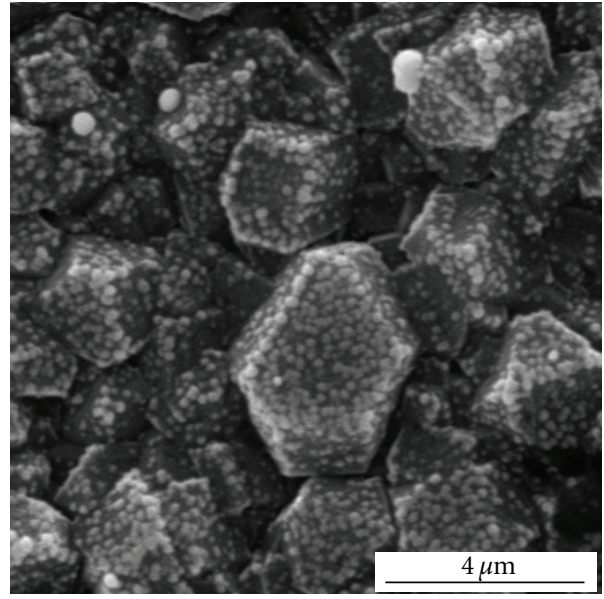

(b)

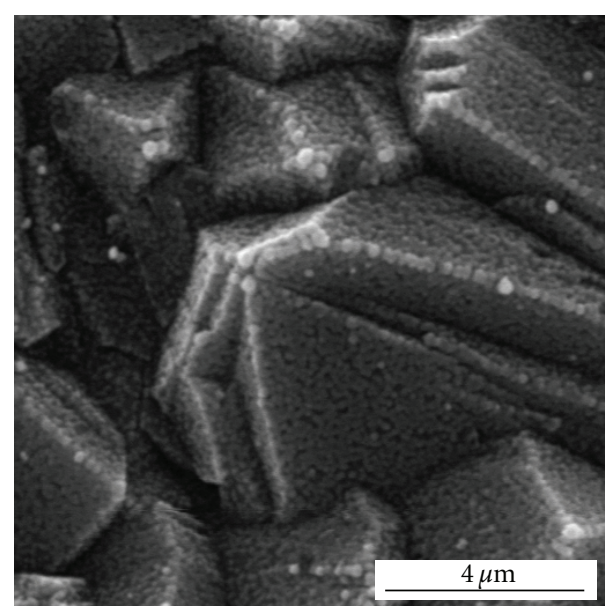

(c)

Figure 5: SEM images of the $\mathrm{Cu} / \mathrm{Pd}$ composite electrodeposited on BDD electrode in solutions with different $\mathrm{Cu}(\mathrm{II}): \mathrm{Pd}(\mathrm{II}) \mathrm{ratio}$ : (a) (1: 1 ), (b) $(5: 1)$, and (c) $10: 1$. All were deposited applying $-0.3 \mathrm{~V}$ by $120 \mathrm{~s}$.

TABle 1: Elemental composition (C, O, Cu, and $\mathrm{Pd}$ ) determined by EDX analysis of the $\mathrm{Cu} / \mathrm{Pd}$ composites electrodeposited on BDD electrode in solutions with different $\mathrm{Cu}(\mathrm{II})$ : $\mathrm{Pd}(\mathrm{II})$ ratio. All were deposited applying $-0.3 \mathrm{~V}$ by $120 \mathrm{~s}$.

\begin{tabular}{lcccc}
\hline \multirow{2}{*}{$\mathrm{Cu}(\mathrm{II}): \mathrm{Pd}(\mathrm{II})$ ratio } & $\mathrm{C}$ & $\mathrm{O}$ & $\mathrm{Cu}$ & $\mathrm{Pd}$ \\
\hline$(1: 1)$ & 89.13 & 0.99 & 1.17 & 8.71 \\
$(5: 1)$ & 81.04 & 3.71 & 6.85 & 8.40 \\
$(10: 1)$ & 49.22 & 12.95 & 28.21 & 9.62 \\
\hline
\end{tabular}

the other hand, the $\mathrm{C}$ content decreases, as function of the $\mathrm{Cu}(\mathrm{II}): \mathrm{Pd}(\mathrm{II})$ ratio increase was verified. This result can be better visualized from the SEM image illustrated in Figure 5(c), where the BDD surface was completely covered by $\mathrm{Cu} / \mathrm{Pd}$ coating. The increase of the $\mathrm{O}$ content in these composites may be associated to the copper oxide formation, since the $\mathrm{O}$ content was not found in the pure $\mathrm{Pd}$ electrodeposit. About $8.5 \%$ at. of $\mathrm{Pd}$ was found in all the $\mathrm{Cu} / \mathrm{Pd}$ composites. As expected, an increase of the atomic ratio between $\mathrm{Cu}$ and $\mathrm{Pd}$ as function of the $\mathrm{Cu}$ (II) concentration increase was verified.

After the electrochemical, morphological, and composition analyses, the $\mathrm{Cu} / \mathrm{Pd}$-modified BDD electrodes were used in the electrochemical reduction of nitrate. This investigation was carried out using $0.1 \mathrm{M} \mathrm{KNO}_{3}+\mathrm{BR}$ buffer solutions at extreme $\mathrm{pH}$ values $(\mathrm{pH} 1.9$ and 9.0). In our initial experiments, the best condition for analyzing the nitrate response was obtained using BR buffer solution ( $\mathrm{pH} 9$ ). This condition was also achieved by other authors in their studies on $\mathrm{Cu} / \mathrm{Pd}$ alloy modified by $\mathrm{Pt}$ and $\mathrm{Ni}$ electrodes $[34,35]$. Figure 6(a) presents the LSV curves of the BDD electrode and $\mathrm{Cu} / \mathrm{Pd}$-modified BDD electrode in BR buffer solution $\mathrm{pH}$ 9. The BDD electrode shows no significant current $(3.9 \mu \mathrm{A}$ at $-1.3 \mathrm{~V})$ for hydrogen evolution reaction. In contrast, the water reduction was verified to occur at more positive potentials on $\mathrm{Cu} / \mathrm{Pd}$ modified BDD electrode, where a high current $(0.94 \mathrm{~mA}$, at $-1.3 \mathrm{~V})$ was involved. At $-1.3 \mathrm{~V}$, a current increase of 240 times confirms the high catalytic capacity of modified BDD electrode for water reduction. 


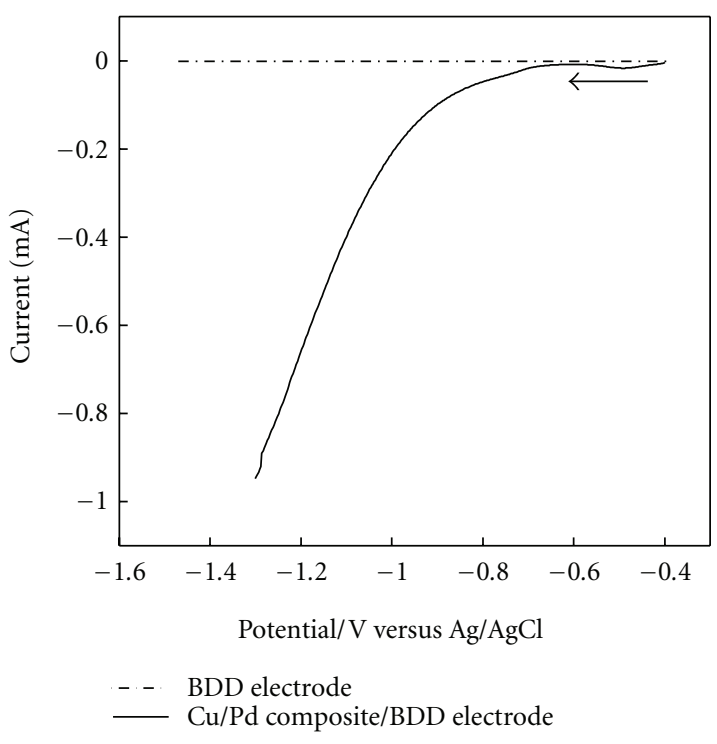

(a)

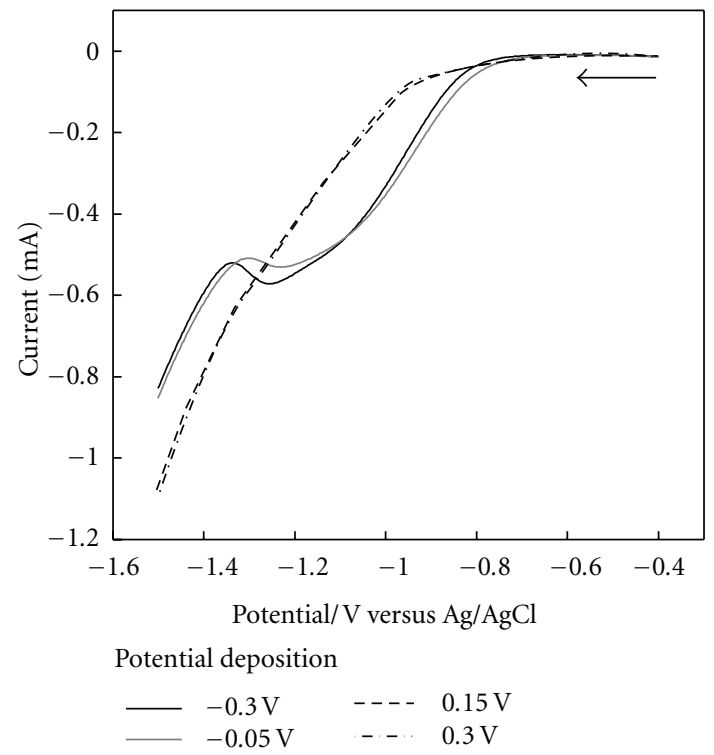

(c)

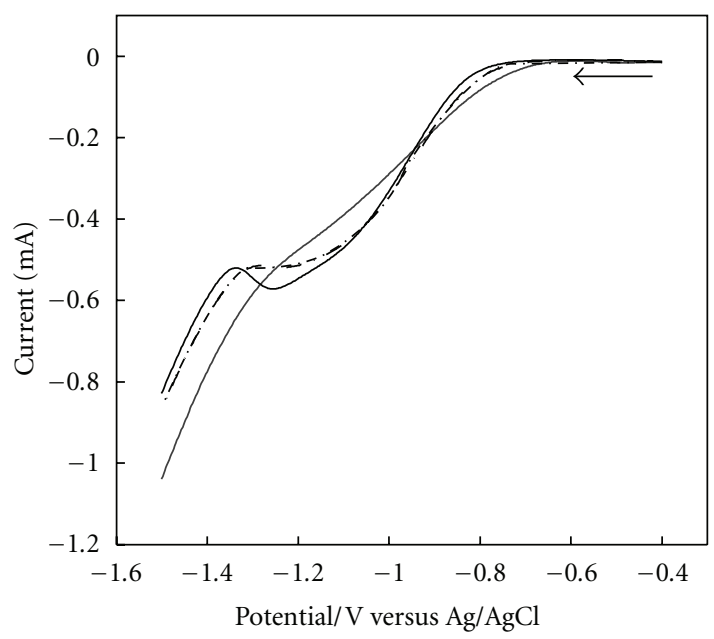

Deposition time

$-30 \mathrm{~s}-120 \mathrm{~s}$

(b)

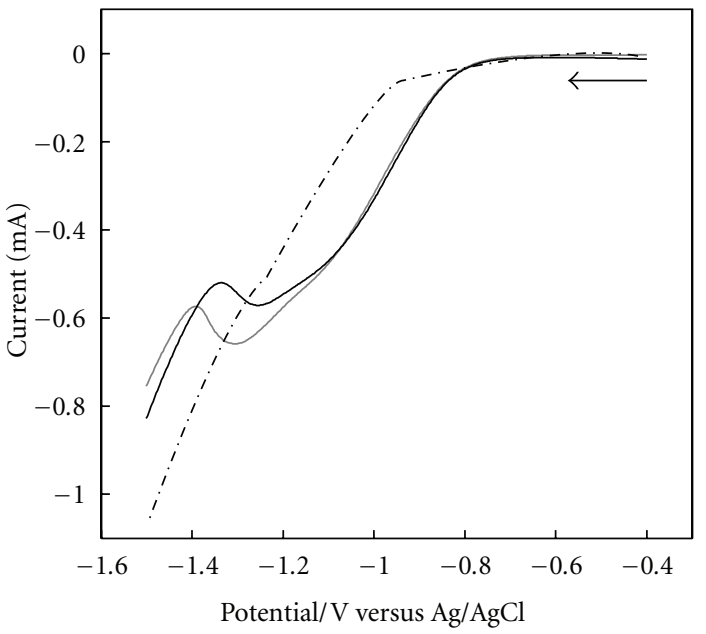

$\mathrm{Cu}(\mathrm{II}) / \mathrm{Pd}(\mathrm{II})$ ratio

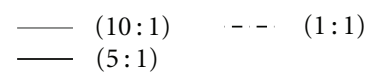

(d)

Figure 6: (a) LSV curves of the BDD and Cu/Pd-modified BDD electrodes in BR buffer solution ( $\mathrm{pH}$ 9). Nitrate response of the Cu/Pd composite electrodeposited on BDD electrode at different (b) deposition time, (c) deposition potential, and (d) $\mathrm{Cu}$ (II) : $\mathrm{Pd}$ (II) ratio. The nitrate response in (b) (c), and (d) was investigated in $0.1 \mathrm{M} \mathrm{KNO}_{3}+\mathrm{BR}$ buffer solution ( $\mathrm{pH}$ 9). The $\mathrm{Cu} / \mathrm{Pd}$ composite used in (a), (b), and (c) was electrodeposited using $5 \mathrm{mM} \mathrm{Cu}(\mathrm{II})+1 \mathrm{mM} \mathrm{Pd}(\mathrm{II})+0.5 \mathrm{M} \mathrm{HClO}_{4}$. Scan rate of $10 \mathrm{mV} \mathrm{s}^{-1}$.

From these results, nitrate response on $\mathrm{Cu} / \mathrm{Pd}$ modified BDD electrode was investigated using different electrodeposition conditions of the $\mathrm{Cu} / \mathrm{Pd}$ composite such as deposition time (Figure 6(b)), deposition potential (Figure 6(c)), and $\mathrm{Cu}(\mathrm{II})$ concentration (Figure 6(d)). Such conditions were focused to obtain $\mathrm{Cu} / \mathrm{Pd}$ composites with different ranges and then evaluate the nitrate reduction. The definition of scan onset from $-0.4 \mathrm{~V}$ to $-1.5 \mathrm{~V}$ was performed in the region where no reactions involving the $\mathrm{Cu} / \mathrm{Pd}$ occur. Figure 6(b) shows the LSV curves from the $\mathrm{Cu} / \mathrm{Pd}$ composite electrodeposited at different deposition time in $0.1 \mathrm{M} \mathrm{KNO}_{3}$
$+\mathrm{BR}$ buffer solution ( $\mathrm{pH}$ 9). A peak current about $-1.25 \mathrm{~V}$ is observed for the $\mathrm{Cu} / \mathrm{Pd}$ composite electrodeposited by $120 \mathrm{~s}$ and may be attributed to nitrate reduction, which was not observed in the blank solution, as can be seen in Figure 6(a). Nitrate analysis was also carried out using $\mathrm{Cu}$ and $\mathrm{Pd}$ electrodeposits on BDD electrode for the same experimental conditions. The nitrate response on $\mathrm{Cu}$-modified $\mathrm{BDD}$ electrode was not possible to analyze due to poor adherence of $\mathrm{Cu}$, while the nitrate reduction on Pd electrodeposit was not observed due to more electrocatalytic efficiency with respect to hydrogen evolution reaction. The best nitrate 
response was verified to depend on the deposition time of $\mathrm{Cu} / \mathrm{Pd}$ composite, where the reduction peak current cannot be seen at short deposition time. It was also studied the nitrate response at long time of $\mathrm{Cu} / \mathrm{Pd}$ composite deposition (not shown), but a negligible variation of the current peak intensity was verified. From these results, the existence of a limited time condition to produce a composite with welldefined characteristics to increase the sensitivity for the nitrate reduction is evident. A cathodic peak of nitrate reduction close to $-1.25 \mathrm{~V}$ was also observed by Reyter et al. in their electrocatalytics tests realized in alkaline medium using $\mathrm{Cu}-\mathrm{Pd}$ alloys produced on $\mathrm{Ni}$ electrode. In this study, maximum currents of nitrate reduction at different potentials were observed over a wide range of elemental composition [35]. Milhano and Pletcher studying $\mathrm{Cu}-\mathrm{Pd}$ alloys electrodeposited on Pt microdisc electrode observed that nitrate reductions commencing close to $-1.2 \mathrm{~V}$ in alkaline medium, but two nitrate reduction processes were noted [34].

In an attempt to enhance the efficiency of nitrate reduction, the $\mathrm{Cu}-\mathrm{Pd}$ system electrodeposited at several deposition potentials, covering a wide range of elemental composition was investigated. The LSV curves are illustrated in Figure 6(c). In a potential region close to bulk $\mathrm{Cu}$ deposition $(-0.05 \mathrm{~V}$ to $-0.3 \mathrm{~V})$, the nitrate reduction was observed. On the other hand, nitrate reduction wave at potential corresponding to the $\mathrm{Cu} / \mathrm{Pd}$ phase formation $(+0.15 \mathrm{~V}$ and $+0.30 \mathrm{~V}$, resp. $)$ was not observed. Such behavior makes us believe that higher $\mathrm{Cu}$ content is necessary to improve the catalytic activity of nitrate reduction. In this case, the $\mathrm{Cu} / \mathrm{Pd}$ phase coating may improve the adherence of $\mathrm{Cu}$ particles. However, electrocatalytic activity, with this coating to reduce nitrate, was not evidenced. The latter investigation involved the nitrate response using $\mathrm{Cu} / \mathrm{Pd}$ modified BDD electrode electrodeposited in solutions with different $\mathrm{Cu}(\mathrm{II}): \mathrm{Pd}(\mathrm{II})$ ratio. The LSV curves are presented in Figure 6(d). From these results, it was possible to confirm all discussion previously made, where a higher cathodic current associated to nitrate reduction and commencing at the same potential was verified for the composite with higher $\mathrm{Cu}$ content. Besides, the peak potential shift of nitrate reduction to a more negative was verified at $\mathrm{Cu} / \mathrm{Pd}$ composite electrodeposited in solution with $(10: 1) \mathrm{Cu}(\mathrm{II}): \mathrm{Pd}(\mathrm{II})$ ratio, showing a more required energy to reduce nitrate.

\section{Conclusions}

In this work, the electrochemical characterization in the solution containing only $\mathrm{Cu}(\mathrm{II})$ ions, $\mathrm{Pd}(\mathrm{II})$, ions and a mixture of the two metal ions performed by cyclic voltammetry was fundamental to evaluate the formation of a $\mathrm{Cu} / \mathrm{Pd}$ bimetallic system on BDD electrode. From the voltammetric curves, $\mathrm{Cu}$ with different phases and a $\mathrm{Cu} / \mathrm{Pd}$ phase were verified to be formed in $\mathrm{Cu} / \mathrm{Pd}$ composite. The deposition of $\mathrm{Cu}$ different phases depended upon the $\mathrm{Cu}(\mathrm{II}): \mathrm{Pd}(\mathrm{II})$ ratio, where the bulk $\mathrm{Cu}$ phase in solution with $(1: 1)$ $\mathrm{Cu}(\mathrm{II}): \mathrm{Pd}(\mathrm{II})$ ratio was not observed. The formed $\mathrm{Cu} / \mathrm{Pd}$ phase was characterized from the potential shift to more negative values and an increase of anodic current to compare the $\mathrm{A} 1$ process $(\mathrm{Cu} / \mathrm{Pd}$ stripping) and the bulk Pd stripping. From the morphological analysis it was possible to verify the different particles sizes deposited and also their composition. As expected, a higher $\mathrm{Cu}$ content was verified at the $\mathrm{Cu} / \mathrm{Pd}$ composite electrodeposited in solution with highest $\mathrm{Cu}(\mathrm{II})$ concentration. On the other hand, the $\mathrm{Cu}$ and $\mathrm{Pd}$ content at $\mathrm{Cu} / \mathrm{Pd}$ phase remained constant, independently of the $(\mathrm{Cu}(\mathrm{II}): \mathrm{Pd}(\mathrm{II})$ ratio used in solution. The $\mathrm{Cu} / \mathrm{Pd}-$ modified BDD electrodes, tested as electrocatalysts for nitrate reduction, showed the best electrocatalytic activity for composites with higher $\mathrm{Cu}$ content, and formed $\mathrm{Cu} / \mathrm{Pd}$ phase, was fundamental to improve the $\mathrm{Cu}$ adherence on BDD electrode.

\section{Acknowledgments}

The authors are so grateful to Brazilian Agencies CAPES (Process no. 02491/09-5), CNPq (processes 471356/2006and 9305009/2006-0), and FAPESP (Processes nos. 05/51387-6, 07/00013-4, and 2009/10661-9) by the financial support. Special thanks to Maria Lucia Brison by SEM and EDX analyses.

\section{References}

[1] K. H. Gelberg, L. Church, G. Casey et al., "Nitrate levels in drinking water in rural New York State," Environmental Research, vol. 80, no. 1, pp. 34-40, 1999.

[2] H. Borcherding, S. Leikefeld, C. Frey, S. Diekmann, and P. Steinrücke, "Enzymatic microtiter plate-based nitrate detection in environmental and medical analysis," Analytical Biochemistry, vol. 282, no. 1, pp. 1-9, 2000.

[3] K. Bouzek, M. Paidar, A. Sadílková, and H. Bergmann, "Electrochemical reduction of nitrate in weakly alkaline solutions," Journal of Applied Electrochemistry, vol. 31, no. 11, pp. 11851193, 2001.

[4] G. E. Dima, A. C. A. De Vooys, and M. T. M. Koper, "Electrocatalytic reduction of nitrate at low concentration on coinage and transition-metal electrodes in acid solutions," Journal of Electroanalytical Chemistry, vol. 554-555, no. 1, pp. 15-23, 2003.

[5] H. L. Li, J. Q. Chambers, and D. T. Hobbs, "Electroreduction of nitrate ions in concentrated sodium hydroxide solutions at lead, zinc, nickel and phthalocyanine-modified electrodes," Journal of Applied Electrochemistry, vol. 18, no. 3, pp. 454-458, 1988.

[6] M. C. P. M. Da Cunha, M. Weber, and F. C. Nart, "On the adsorption and reduction of $\mathrm{NO}_{3}$ - ions at $\mathrm{Au}$ and $\mathrm{Pt}$ electrodes studied by in situ FTIR spectroscopy," Journal of Electroanalytical Chemistry, vol. 414, no. 2, pp. 163-170, 1996.

[7] C. Lévy-Clément, N. A. Ndao, A. Katty et al., "Boron doped diamond electrodes for nitrate elimination in concentrated wastewater," Diamond and Related Materials, vol. 12, no. 3-7, pp. 606-612, 2003.

[8] F. Bouamrane, A. Tadjeddine, J. E. Butler, R. Tenne, and C. Lévy-Clément, "Electrochemical study of diamond thin films in neutral and basic solutions of nitrate," Journal of Electroanalytical Chemistry, vol. 405, no. 1-2, pp. 95-99, 1996.

[9] C. Reuben, E. Galun, H. Cohen et al., "Efficient reduction of nitrite and nitrate to ammonia using thin-film B-doped 
diamond electrodes," Journal of Electroanalytical Chemistry, vol. 396, no. 1-2, pp. 233-239, 1995.

[10] R. Tenne, K. Patel, K. Hashimoto, and A. Fujishima, "Efficient electrochemical reduction of nitrate to ammonia using conductive diamond film electrodes," Journal of Electroanalytical Chemistry, vol. 347, no. 1-2, pp. 409-415, 1993.

[11] M. C. Granger, M. Witek, J. Xu et al., "Standard electrochemical behavior of high-quality, boron-doped polycrystalline diamond thin-film electrodes," Analytical Chemistry, vol. 72, no. 16, pp. 3793-3804, 2000.

[12] J. A. Bennett, J. Wang, Y. Show, and G. M. Swain, "Effect of $\mathrm{sp}^{2}$-bonded nondiamond carbon impurity on the response of boron-doped polycrystalline diamond thin-film electrodes," Journal of the Electrochemical Society, vol. 151, no. 9, pp. E306E313, 2004.

[13] M. C. P. M. da Cunha, J. P. I. De Souza, and F. C. Nart, "Reaction pathways for reduction of nitrate ions on platinum, rhodium, and platinum-rhodium alloy electrodes," Langmuir, vol. 16, no. 2, pp. 771-777, 2000.

[14] C. Lu, S. Lu, W. Qiu, and Q. Liu, "Electroreduction of nitrate to ammonia in alkaline solutions using hydrogen storage alloy cathodes," Electrochimica Acta, vol. 44, no. 13, pp. 2193-2197, 1999.

[15] J. F. E. Gootzen, L. Lefferts, and J. A. R. Van Veen, "Electrocatalytic nitrate reduction on palladium based catalysts activated with germanium," Applied Catalysis A: General, vol. 188, no. 1-2, pp. 127-136, 1999.

[16] J. F. E. Gootzen, P. G. J. M. Peeters, J. M. B. Dukers, L. Lefferts, W. Visscher, and J. A. R. Van Veen, "The electrocatalytic reduction of $\mathrm{NO}_{-3}$ on $\mathrm{Pt}, \mathrm{Pd}$ and $\mathrm{Pt}+\mathrm{Pd}$ electrodes activated with Ge," Journal of Electroanalytical Chemistry, vol. 434, no. 1-2, pp. 171-183, 1997.

[17] F. J. G. de Dios, R. Gómez, and J. M. Feliu, "Preparation and electrocatalytic activity of Rh adlayers on $\operatorname{Pt}\left(\begin{array}{lll}1 & 0 & 0\end{array}\right)$ electrodes: reduction of nitrous oxide," Electrochemistry Communications, vol. 3, no. 11, pp. 659-664, 2001.

[18] O. A. Petrii and T. Y. Safonova, "Electroreduction of nitrate and nitrite anions on platinum metals: A model process for elucidating the nature of the passivation by hydrogen adsorption," Journal of Electroanalytical Chemistry, vol. 331, no. 1-2, pp. 897-912, 1992.

[19] T. Y. Safonova and O. A. Petrii, "Effect of inorganic cations on the electroreduction of nitrate anions on $\mathrm{Pt}-\mathrm{Pt}$ electrodes in sulfuric acid solutions," Journal of Electroanalytical Chemistry, vol. 448, no. 2, pp. 211-216, 1998.

[20] K. Shimazu, T. Kawaguchi, and K. Tada, "Preparation of binary metal electrocatalysts by self-assembly of precursor ionic species on gold and reduction of nitrate ions," Journal of Electroanalytical Chemistry, vol. 529, no. 1, pp. 20-27, 2002.

[21] K. Shimazu, R. Goto, and K. Tada, "Electrochemical reduction of nitrate ions on tin-modified platinum and palladium electrodes," Chemistry Letters, no. 2, pp. 204-205, 2002.

[22] B. E. Roustom, G. Fóti, and C. Comninellis, "Preparation of gold nanoparticles by heat treatment of sputter deposited gold on boron-doped diamond film electrode," Electrochemistry Communications, vol. 7, no. 4, pp. 398-405, 2005.

[23] Y. Zhang, S. Asahina, S. Yoshihara, and T. Shirakashi, "Oxygen reduction on $\mathrm{Au}$ nanoparticle deposited boron-doped diamond films," Electrochimica Acta, vol. 48, no. 6, pp. 741-747, 2003.

[24] Y. Zhang, V. Suryanarayanan, I. Nakazawa, S. Yoshihara, and T. Shirakashi, "Electrochemical behavior of Au nanoparticle deposited on as-grown and O-terminated diamond electrodes for oxygen reduction in alkaline solution," Electrochimica Acta, vol. 49, no. 28, pp. 5235-5240, 2004.

[25] F. Montilla, E. Morallón, I. Duo, C. Comninellis, and J. L. Vázquez, "Platinum particles deposited on synthetic borondoped diamond surfaces. Application to methanol oxidation," Electrochimica Acta, vol. 48, no. 25-26, pp. 3891-3897, 2003.

[26] G. Siné and C. Comninellis, "Nafion-assisted deposition of microemulsion-synthesized platinum nanoparticles on BDD: activation by electrogenerated $\mathrm{OH}$ radicals," Electrochimica Acta, vol. 50, no. 11, pp. 2249-2254, 2005.

[27] K. Tsujimoto, S. Mitani, T. Teraji, and T. Ito, "Fabrication of nano-sized platinum particles self-assembled on and in CVD diamond films," Applied Surface Science, vol. 237, no. 1-4, pp. 488-493, 2004.

[28] C. M. Welch, M. E. Hyde, C. E. Banks, and R. G. Compton, "The detection of nitrate using in-situ copper nanoparticle deposition at a boron doped diamond electrode," Analytical Sciences, vol. 21, no. 12, pp. 1421-1430, 2005.

[29] S. Ward-Jones, C. E. Banks, A. O. Simm, L. Jiang, and R. G. Compton, "An in situ copper plated boron-doped diamond microelectrode array for the sensitive electrochemical detection of nitrate," Electroanalysis, vol. 17, no. 20, pp. 1806-1815, 2005.

[30] K. Bouzek, M. Paidar, A. Sadílková, and H. Bergmann, "Electrochemical reduction of nitrate in weakly alkaline solutions," Journal of Applied Electrochemistry, vol. 31, no. 11, pp. 11851193, 2001.

[31] A. C. A. de Vooys, R. A. van Santen, and J. A. R. Van Veen, "Electrocatalytic reduction of $\mathrm{NO}_{3}$ on palladium/copper electrodes," Journal of Molecular Catalysis A, vol. 154, no. 1-2, pp. 203-215, 2000.

[32] O. Ghodbane, M. Sarrazin, L. Roué, and D. Bélanger, "Electrochemical reduction of nitrate on pyrolytic graphite-supported $\mathrm{Cu}$ and Pd-Cu electrocatalysts," Journal of the Electrochemical Society, vol. 155, no. 6, pp. F117-F123, 2008.

[33] S. N. Vinogradov, G. N. Mal'tseva, and N. A. Gulyaeva, "Electrodeposition of a palladium-copper alloy in non-steadystate electrolysis," Russian Journal of Electrochemistry, vol. 37, no. 7, pp. 715-717, 2001.

[34] C. Milhano and D. Pletcher, "The electrodeposition and electrocatalytic properties of copper-palladium alloys," Journal of Electroanalytical Chemistry, vol. 614, no. 1-2, pp. 24-30, 2008.

[35] D. Reyter, D. Bélanger, and L. Roué, "Elaboration of Cu-Pd films by coelectrodeposition: application to nitrate electroreduction," Journal of Physical Chemistry C, vol. 113, no. 1, pp. 290-297, 2009.

[36] N. G. Ferreira, L. L. G. Silva, E. J. Corat, V. J. Trava-Airoldi, and K. Iha, "Electrochemical characterization on semiconductors p-type CVD diamond electrodes," Brazilian Journal of Physics, vol. 29, no. 4, pp. 760-763, 1999.

[37] P. W. May, W. J. Ludlow, M. Hannaway, P. J. Heard, J. A. Smith, and K. N. Rosser, "Raman and conductivity studies of borondoped microcrystalline diamond, facetted nanocrystalline diamond and cauliflower diamond films," Diamond and Related Materials, vol. 15, no. 2, pp. 105-117, 2008.

[38] R. J. Zhang, S. T. Lee, and Y. W. Lam, "Characterization of heavily boron-doped diamond films," Diamond and Related Materials, vol. 5, no. 11, pp. 1288-1294, 1996.

[39] F. Bouamrane, A. Tadjeddine, R. Tenne, J. E. Butler, R. Kalish, and C. Lévy-Clément, "Underpotential deposition of $\mathrm{Cu}$ on boron-doped diamond thin films," Journal of Physical Chemistry B, vol. 102, no. 1, pp. 134-140, 1998. 
[40] B. H. Vassos and H. B. Mark, "The anodic dissolution of thin films of copper metal from pyrolytic graphite: a study of the multiple dissolution current peaks," Journal of Electroanalytical Chemistry, vol. 13, no. 1-2, pp. 1-9, 1967. 


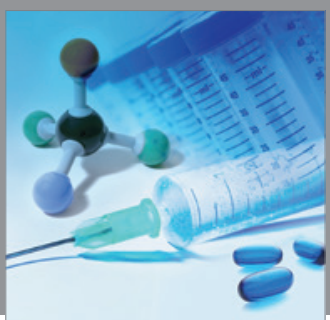

International Journal of

Medicinal Chemistry

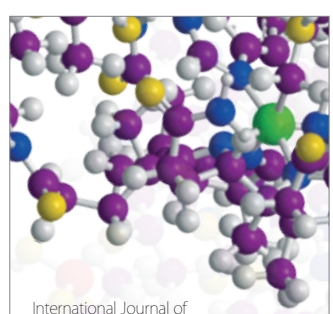

Carbohydrate Chemistry

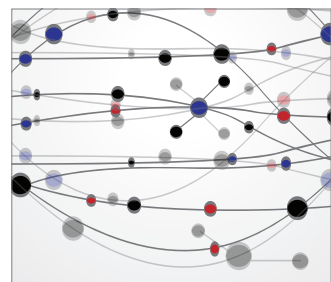

The Scientific World Journal
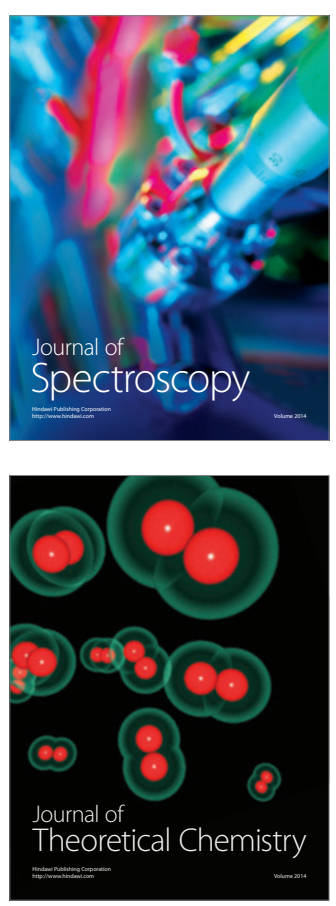
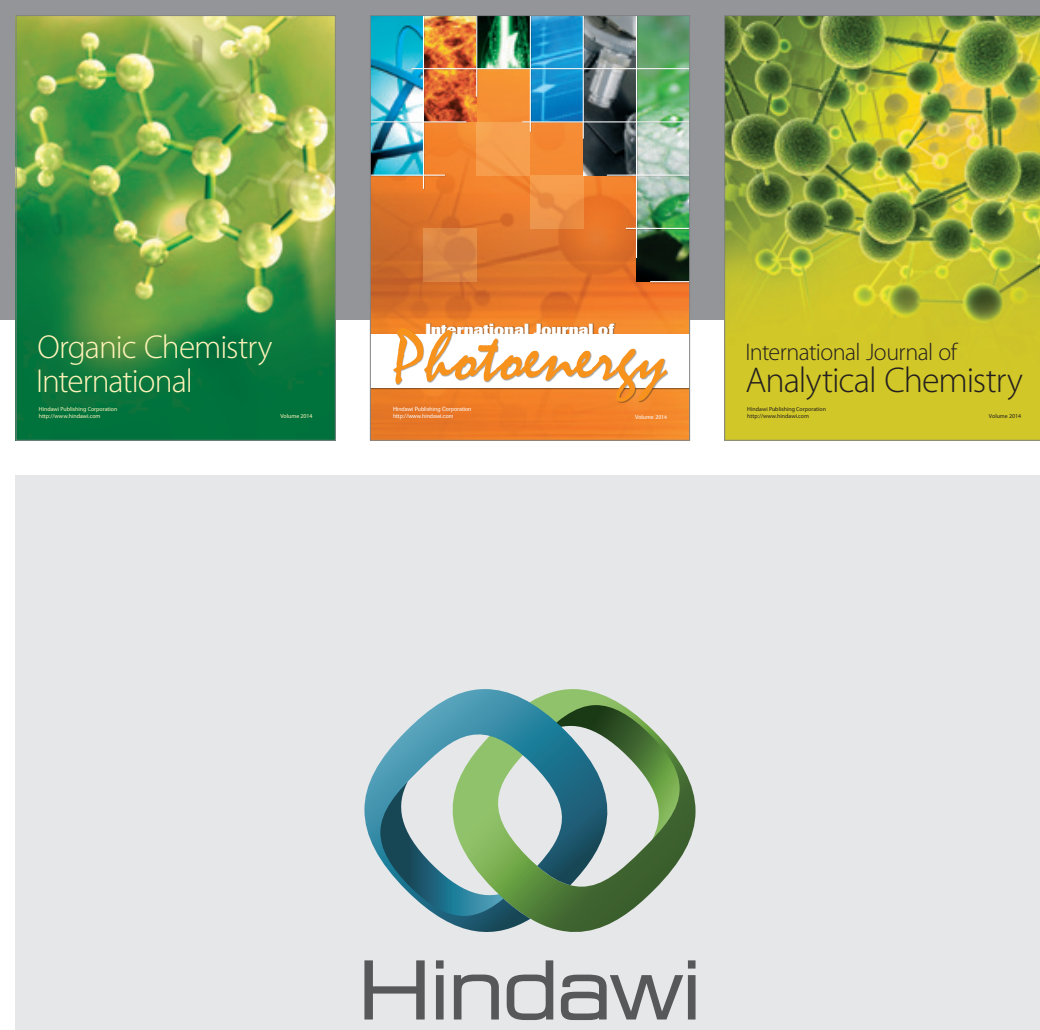

Submit your manuscripts at

http://www.hindawi.com
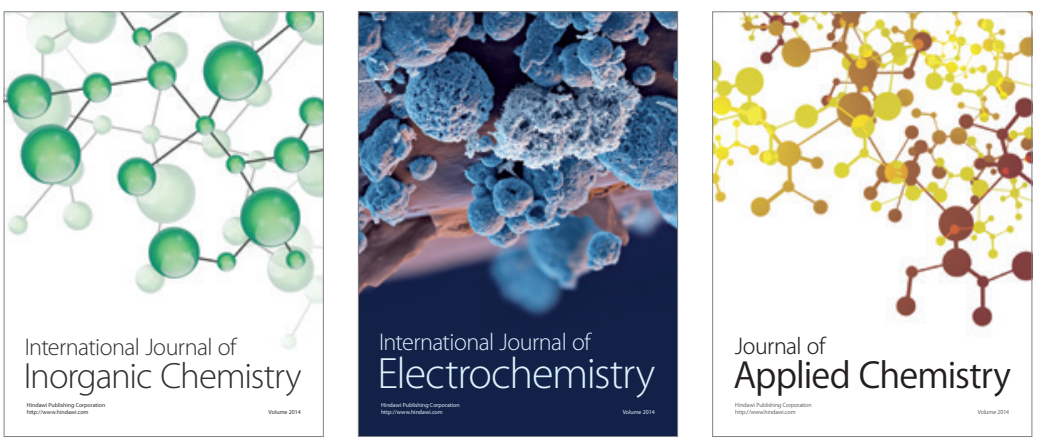

Journal of

Applied Chemistry
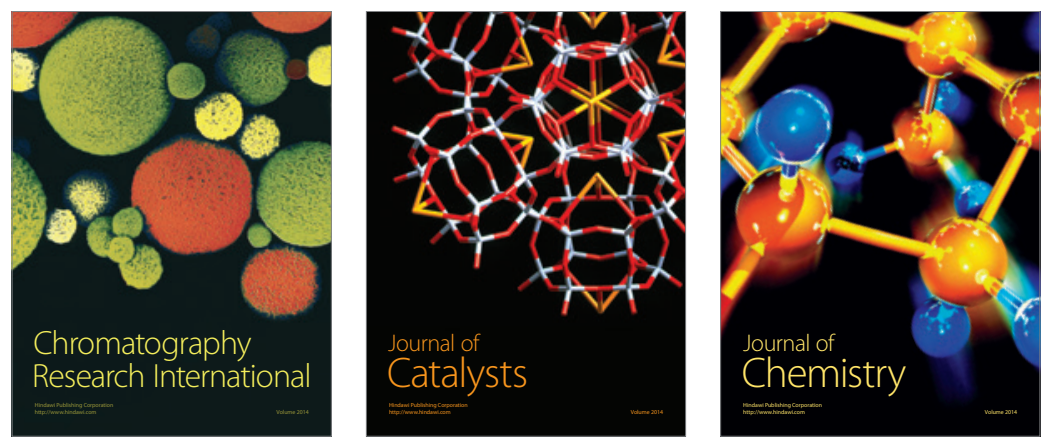
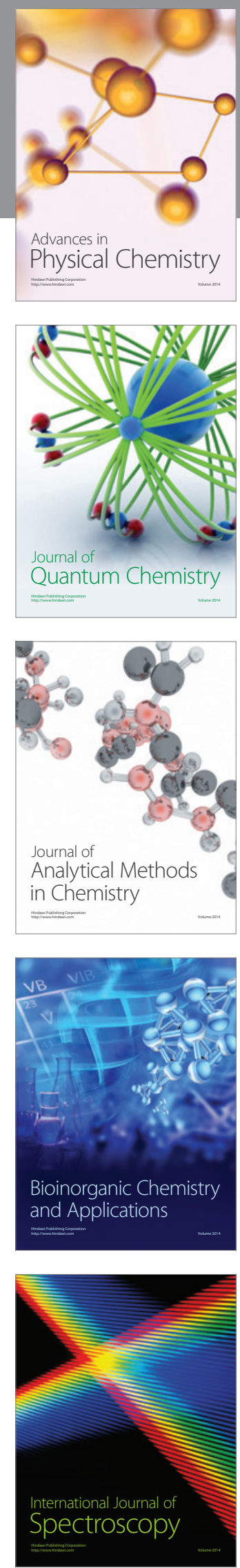